\title{
INNOVATION CAPABILITIES AND PERFORMANCE OF MALAYSIAN AGRICULTURAL SMEs: THE MODERATING ROLE OF STRATEGIC ALLIANCE
}

\author{
Nurul Izni Kamalrulzaman \\ Universiti Malaysia Terengganu, Malaysia \\ Azlinzuraini Ahmad* \\ Universiti Malaysia Terengganu, Malaysia \\ Akmalia Mohamad Ariff \\ Universiti Malaysia Terengganu, Malaysia \\ Mohd Shaladdin Muda \\ Universiti Malaysia Terengganu, Malaysia
}

\begin{abstract}
Small and Medium Enterprises (SMEs) in the agriculture sector in Malaysia are still seen to contribute only a small portion towards Gross Domestic Product (GDP) and the total number of the national workforce. As for agricultural SMEs, innovation activities are needed to produce quality agricultural-based products to meet the increasing of Malaysia and world market demand. Nevertheless, innovation among agricultural SMEs is still less encouraging. Hence, this study aims to investigate the effect of innovation capabilities towards performance of agricultural SMEs in Malaysia and determine the role of strategic alliance as a moderator in influencing the performance of agricultural SMEs. The conceptual framework of innovation capabilities is based on Resource-Based View Theory and Schumpeter Innovation Theory that considers strategic alliance will positively affect the relationship between innovation capabilities and SME performance. A total of 136 respondents from Agricultural SMEs were used for data analysis process using SmartPLS 3.0 software. The results show that innovation capabilities have a positive impact on the performance of SMEs, while strategic alliance does not affect the relationship between innovation capabilities and agricultural SME performance. Although strategic alliance has insignificant effect, this might be resulted from the emphasis of this study as it defined strategic alliances as acquisitions of companies. For agricultural SMEs in Malaysia, entrepreneurs need to look at an alliance from a positive perspective by looking it as a joint venture process in resource sharing that will benefit the enterprises, thus it is not only meant acquisition. The implication of this study is expected to contribute and enhance the role of innovation capabilities among entrepreneurs and strategic alliances in the Malaysian agricultural SMEs.
\end{abstract}

Keywords: Strategic Alliance, Innovation Capabilities, Firm Performance, Agricultural SMEs.

Received: 24 April 2019

Accepted: 10 May 2021

https://doi.org/10.33736/ijbs.3751.2021

\footnotetext{
* Corresponding author: Faculty of Business, Economics and Social Development, Universiti Malaysia Terengganu, 21030 Kuala Nerus, Terengganu, Malaysia, 09-6684157/4158/4241, azlinzuraini@umt.edu.my
} 


\section{INTRODUCTION}

In the context of a developing country such as Malaysia, innovation is seen as a catalyst in the development and growth of the economy, especially the Small Medium Enterprises (SMEs). GE Global Innovation Barometer 2016 shows that 16\% of the Malaysian SMEs have been increased in revenue and profit as compared to larger companies. In Malaysia, studies on the effect of innovation capabilities on firm performance have been conducted in the hotel industry (Asree et al., 2010), wood and timber industry (Hassan et al., 2014) and food manufacturing (Abd Aziz \& Samad, 2016; Adnan \& Ahmad, 2016). The findings generally indicate that innovation capabilities have positive impact towards SMEs performance. Despite the evidence, the fact that innovation capabilities can be industry-specific, as well as customer-specific, warrant further research on the role of innovation in influencing the performance of SMEs specifically for agricultural sector. The Malaysian agricultural SMEs provides a unique research setting to focus on innovation capabilities, strategic alliance and performance. The issue is considered timely and relevant due to the following reasons. First, there is a pressing need to escalate the performance of the agricultural industry in Malaysia in order to keep up with the challenges in the global agricultural industry. According to Food and Agriculture (OECD/FAO) (2017), the agriculture and food sectors need to produce 50\% more food and biofuel sources in 2050, as compared to those in 2012, to fulfil the demand of food supplies due to the increase in human population in 2050. Other than the increase in demand, the global agriculture industry serves in eradicating poverty in the rural areas in line with the United Nations' Sustainable Development Goals (SDGs). Second, the agriculture industry is one of the important contributors to the GDP and has an important role in the development of other sectors in Malaysian economy such as industrial and service sectors, and the downstream sectors (Zainal Abidin et al., 2015). The value added of agriculture sector in 2017 was RM 54.9 billion, an increase of $15 \%$ compared to RM 41.5 billion in 2015 (Jabatan Perangkaan Malaysia, 2018). Third, there have been a broad spectrum of digital technologies that can reduce costs, or provide solutions to constraints or requirements in a changing environment in the agriculture and food sectors. Examples include the low-tech investments such as the use of mobile devices to help users access services supporting farm management decisions and the high-tech "digital farms" or logistics management services such as making use of integrated systems involving drones, robotics, internet of things (IoT), sensors and big data analytic (Jouanjean, 2019).

In this study, we first examine the relationship between innovation capabilities and the performance of agriculture SMEs in Malaysia. Second, we evaluate whether strategic alliance moderates the relation between innovation capabilities and performance. The motivation of this study is based on two primary considerations. First, despite the various supports by the government from various governmental agencies (SME Corporation Malaysia, 2015), the performance of the SMEs are still vulnerable, especially in their ability to be sustainable in the future. SME statistical performance shows that Malaysian SMEs are still not at par with other developing countries in Asia such as Hong Kong, Philippines, Taiwan, Japan and China (SME Corporation Malaysia, 2015). Second, while innovation activities are needed to produce quality agricultural-based products to meet the increasing demand of the market and to gain competitive advantage, innovation among agricultural SMEs is still less encouraging. The hindering factors include the lack of financial resources, management skills, expert workers, and knowledge on innovation (Abd Aziz \& Samad, 2016; Chow, 2016; Omar et al., 2009). Further, there are weaknesses in the implementation of innovation policy in Malaysia such as the lack of strategy to exploit strategic alliance and lack of expert resources to undertake the innovation activities ( $\mathrm{Ng} \& \mathrm{Kee}, 2013)$. 


\section{LITERATURE REVIEW AND HYPOTHESES DEVELOPMENT}

To face the upcoming challenges in agriculture sector, Malaysian farmers need to adopt technology and innovation in agricultural practices to ensure a more conducive agricultural process that can increase the productivity and efficiency of the operations and reduce costs (Ahmad et al., 2014). There are various types of innovation that can be undertaken by them. Product innovation refers to the introduction of new product and/or significant improvement in the existing products, which can be made on the features, intended use, components and material of the products, aiming to enhance customers' needs and satisfaction (Polder et al., 2010). SMEs can also introduce process innovation, referring to the significant improvement in the production and logistic methods or bringing significant improvements in supporting activities such as purchasing, accounting, maintenance and computing (Polder et al., 2010). Organizational innovation involves new ways of organizing routine activities to bring efficiency in the business (Polder et al., 2010) that result in the reduction of transaction and administrative cost (Karabulut, 2015). Market innovation includes the use of new channels of distribution and new advertising approaches for selling current or new products. According to Walker (2004), these types of innovation influence, and should be implemented in conjunction with, each other.

\subsection{Underlying Theories for Research Framework}

In this study, the performance of Malaysian agriculture SMEs is explored through the lenses of the Resource-Based View Theory. The theory identifies organizational resources as the factors that lead to competitive advantage and improvement in the performance of the organizations. In the context of our study, innovation capabilities and strategic alliance within the organizations are perceived as unique and distinguishable from their competitors, and are not easy to replicate, and thus allowing them to enjoy competitive advantages and gain improvement. However, from the Resource-Based View perspective, innovation does not come simply from scanning the external environment for market opportunities, but it is important for organization to develop innovation by using their internal resources (Kostopoulos et al., 2002). Therefore, this study has also adopted another theory to enhance understanding of innovation capabilities, which is widely known as Schumpeter Innovation Theory. Based on Schumpeter Innovation Theory, this study has adopted four dimensions of innovation which has been classified as product innovation, process innovation, market innovation and organizational innovation. Initially, Schumpeter believed that the main factors influencing economic growth are caused by two factors; the innovation process and the doer of innovation or known as the entrepreneur (Śledzik, 2013). Both theories have reflected to the hypothesis development and our conceptual framework which can be seen in the following subsections of 2.2 till 2.4 .

\subsection{Innovation Capabilities and Performance of SMEs in Malaysia}

The link between innovation capabilities and corporate performance is sourced from various interrelated factors. First, innovation capabilities enhance operating performance such as improving productivity, operating time, and product flexibility (Armbruster et al., 2008) as well as improving product delivery performance (Peng et al., 2008). In this essence, innovation capabilities have a positive impact on quality that will lead to the increased profitability of the company (Cho \& Pucik, 2005). Second, innovation capability is a source of gaining competitive advantage (Walker, 2004). There is evidence that SMEs with high innovation capabilities will have a high 
level of competitiveness compared to their competitors, and that innovation capabilities will enable them to achieve high levels of performance (Rosenbusch et al., 2011; Sok et al., 2013). Third, innovation capabilities allow companies to build their reputation in the marketplace, and thus increase the market share of the companies (Saunila, 2014). In the context of SMEs in Malaysia, innovation is the way for them to remain economically viable in order to continue to contribute to economic performances (Ramlan \& Abd Malek, 2011). This is because the SMEs are continuously experiencing increasing pressure to remain economically viable as their market expand, as they have to start competing with a larger number of companies. The findings of the prior studies in Malaysian context are in support of the role of innovation in improving their performance. Salim and Sulaiman (2011) found that diversity in innovation and information and data sharing has a positive relationship with the improvement in the performance of the SMEs. Mohamad and Sidek (2013), that focus on SMEs in the food and beverage, textiles and apparel and wood-based subindustries, found that product innovation and process innovation had a significant effect on performance of SMEs. Hilmi et al. (2010) found that market innovation and process innovation play an important role in improving the performance of SMEs in Malaysia.

These innovation capabilities allow the agricultural SMEs to meet the increasing demand of local and global market, and continue to contribute to national GDP directly or through the development of other dependent sectors. Agricultural SMEs that take advantage of the advancement in physical and digital technologies are arguably those that will be able to perform well, and sustain their performance, in uncertain economic and physical environment. Yet, there are constraints faced by agricultural SMEs in Malaysia especially in innovation capabilities that have affected their ability in managing and improving the performance of their businesses (Shahadan et al., 2010). Lack of innovation within the enterprises is the reason that the products of the SMEs are not able to compete with products from large companies that mainly practice innovation. Additionally, agricultural SMEs are faced with the issue of using new technology in the production process that has resulted in the increase in costs, impacting on the competition in the country's export activity (Muhammad et al., 2010). Lack of innovation can become the cause of the reduction in SMEs' profits as their production is not able to meet the needs and requirements of the market that is broadening and changing according to the trend of consumer demand.

Therefore, the benefit of innovation capabilities on the performance of Malaysian agricultural SMEs is not that well established. While innovation capabilities are resources that can increase values of companies, and empirical evidence involving companies from various sectors establish the link between innovation capabilities and corporate performance (Abd Aziz \& Samad, 2016; Adnan \& Ahmad, 2016), the opportunities and challenges faced by agricultural SMEs in Malaysia provides a unique setting to explore the role of innovation capabilities. Accordingly, in line with our first research objective, the hypothesis is as follows:

H1: There is a positive relationship between innovation capabilities and the performance of agricultural SMEs in Malaysia:

\subsection{The Moderating Role of Strategic Alliances on the Relation between Innovation Capabilities and Performance}

Strategic alliance is defined as the "partnership" that offers business opportunities by combining resources in creating advantages that can increase profit and market competitiveness (Yi, 2007). 
The need to establish alliances has become an important factor in business activities for various industries as most companies are now competing in a challenging global marketplace. In the perspective of the resource-based view theory, strategic alliances are an alternative for accessing resources from other firms without the risks involved with acquisitions or mergers (Lammi, 2012). As compared to larger companies, SMEs may have more motivations to establish strategic alliances. For SMEs, strategic alliances provide the opportunity for them to improve their performance in ways that are difficult to achieve if they have to do it independently (Sarkar et al., 2001). As for SMEs, strategic alliances can help entrepreneurs to improve their competitiveness, gain new marketplace, share skills and abilities, and share the risks and costs of major development projects (Išoraite, 2009). Based on previous studies such as Rezgui and Miles (2010) and Zeng et al. (2010), strategic alliances are identified as having a positive impact on the performance of SMEs. A company's economic performance is shown to be influenced by the technology partner type, the time frame in entering the joint venture project and the type of company (Cruz-Cázares et al., 2010). Strategic alliance with customers, suppliers, and other companies are shown to benefit more in the innovation process of SMEs as compared to strategic alliances with government agencies, research institutions and universities (Zeng et al., 2010).

Therefore, the extent to which strategic alliances affect the link between innovation capabilities and the performance of SMEs needs to be further explored. In the context of the agricultural SMEs in Malaysia, strategic alliance is expected to enhance the relationship between innovation capabilities and performance. According to Hofstede's cultural score, Malaysia is identified as a country with low uncertainty avoidance, that its people are open for the unknown future. It is also a collectivist country, in which the people are cooperative and think in terms of 'we'. Also, the institutional settings that involve different ethnic groups in the country would have established the cooperative culture in the society and businesses. With these cultural values embedded in the institutional context of Malaysia, strategic alliance is expected to benefit the SMEs in terms of enhancing the likelihood of innovation that accordingly affect positively on their performance. Hence, in addressing our second research objective, the hypothesis of this study is set as follows:

\section{H2: Strategic alliances affect the relationship between innovation capabilities and the performance of agricultural SMEs in Malaysia.}

\subsection{Conceptual Framework Derived from Theories and Literature Review}

The overall conceptual framework of this study is based on the firm's Resource-Based View theory which considers the positive impact of innovation capabilities on SMEs performance, and strategic alliances that positively affect the relationship between innovation capabilities and SMEs performance. Next, innovative capabilities are tested as independent variables which have been adopted from Schumpeter Innovation Theory. For innovation capabilities, there are four dimensions to be tested namely product innovation, process innovation, market innovation and organization innovation. The dependent variable of this study is the performance of SMEs and the main focus of this study is to look at the relationship between innovation capabilities and SMEs performance. Meanwhile, strategic alliances will be tested as a moderator of the study. By combining these two theories, the purpose of this moderator role is to see whether strategic alliances will affect the relationship between innovation capabilities and SMEs performance in agricultural SMEs. Figure 1 illustrates the conceptual framework for this study and Hypothesis 1 and Hypothesis 2 are highlighted. 
Figure 1: Conceptual Framework

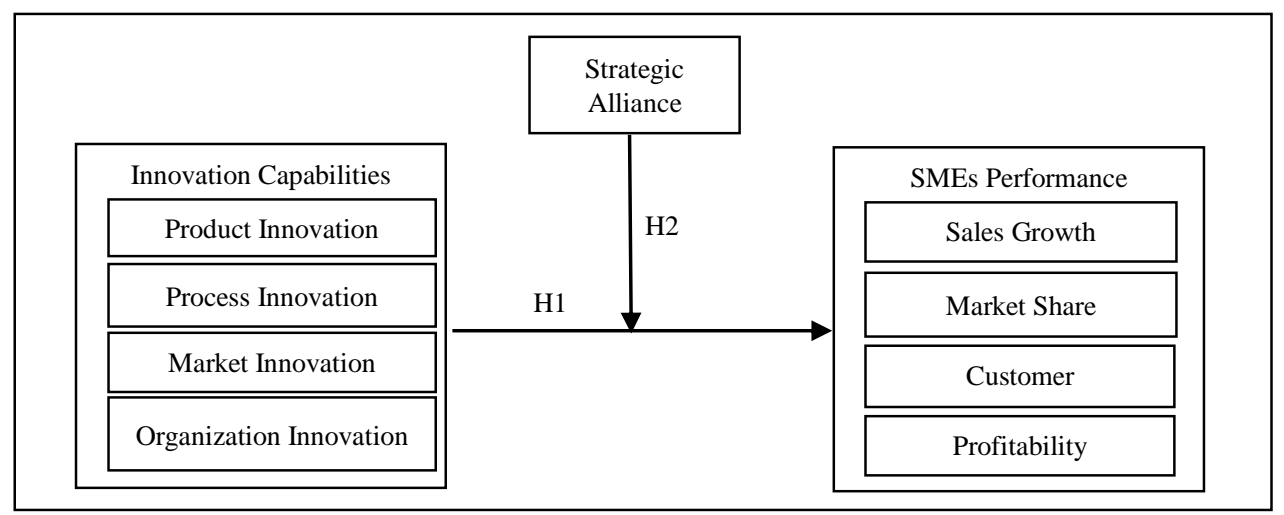

\section{RESEARCH METHODOLOGY}

\subsection{Sampling Design and Data Collection}

A quantitative approach was adopted to examine the relationship between innovation capabilities on agriculture SMEs performance in Malaysia and to evaluate whether strategic alliance moderates the relation between innovation capabilities and performance. The sample was selected by cluster and stratified random sampling and has targeted agriculture SME owners as research respondents from all over Peninsular Malaysia. A set of 350 questionnaires were distributed, of which 136 usable responses have been collected, yielding a response rate of 38.8\%. The Partial Least Square - Structural Equation Modelling (PLS-SEM) software, SmartPLS software version 3.2.7 (Ringle et al., 2015) was used for the inferential analyses of the collected data in this study. The PLS-SEM analysis consists of two stages: i) measurement model validity and reliability analysis (the relationship between the indicators and the constructs), and ii) structural model validation analysis (the relationship between the constructs or hypothesis testing).

\subsection{Measures}

The innovation capabilities were measured using four types of innovation (product innovation, process innovation, market innovation and organization innovation) and they have been represented by 41 items. The items were adapted from previous research namely Community Innovation Survey (2008), Gunday et al. (2011) and Škerlavaj et al. (2010). The measure for strategic alliance was adapted from Išoraite (2009) and consisted of 7 items. Firm performance was measured using items from Stella (2012) and had 26 items. Firm performance refers to sales growth, customer satisfaction, market share and profitability. All items were measured by using five-point Likert Scale from 1 represents "Strongly Disagree" to 5 represents "Strongly Agree" for each construct of the research model. 


\subsection{Respondents Profile}

Among the entrepreneurs, $64.0 \%$ are small sized agriculture firms and the remaining $36.0 \%$ are medium firms. In term of the distribution of respondent by state, the highest rate of respondent was from the state of Terengganu (21.3\%), the second highest were from Kedah (14.7\%), then Selangor $(14.0 \%)$ in the third rate and the fewest respondents were from the state of Perlis $(0.7 \%) .47 .1 \%$ respondents belong in the category of firms age more than 10 years, meanwhile, $44.1 \%$ of respondents were in the category of firms age between 5 to 10 years and $8.8 \%$ of respondents were in the category of firms age less than 5 years. In terms of the type of product, the highest proportion was in crops (58.8\%), 20.6\% of respondents were in livestock, $5.9 \%$ of respondents were in fisheries, $14.0 \%$ were in more than one type of product and the fewest respondents were in forestry and logging $(0.7 \%)$.

\section{DATA ANALYSIS AND RESULTS}

\subsection{Descriptive Statistic}

Descriptive statistics provide details about responses to measurement tool questions (Sekaran \& Bougie, 2010). The descriptive statistics of the respondent perspectives on the variables are highlighted in Table 1.

Table 1: Descriptive Statistic of the Research Variables

\begin{tabular}{lccc}
\hline \hline \multicolumn{1}{c}{ Dimension } & $\mathbf{N}$ & Mean & Std. Deviation \\
\hline Innovation Capabilities & 136 & 3.523 & 0.690 \\
Performance & 136 & 3.610 & 0.747 \\
Strategic Alliance & 136 & 3.490 & 0.800 \\
\hline \hline
\end{tabular}

\subsection{Measurement Model}

Measurement model is to establish the validity of the relationship between items and the constructs in the research framework. There are two types of validity which supposed to be met in the measurement model; convergent validity and discriminant validity. As the study is quantitative in nature, usually Cronbach's alpha is also recommended to ensure reliability. Figure 2 illustrated the measurement model of the study. 
Figure 2: Measurement Model

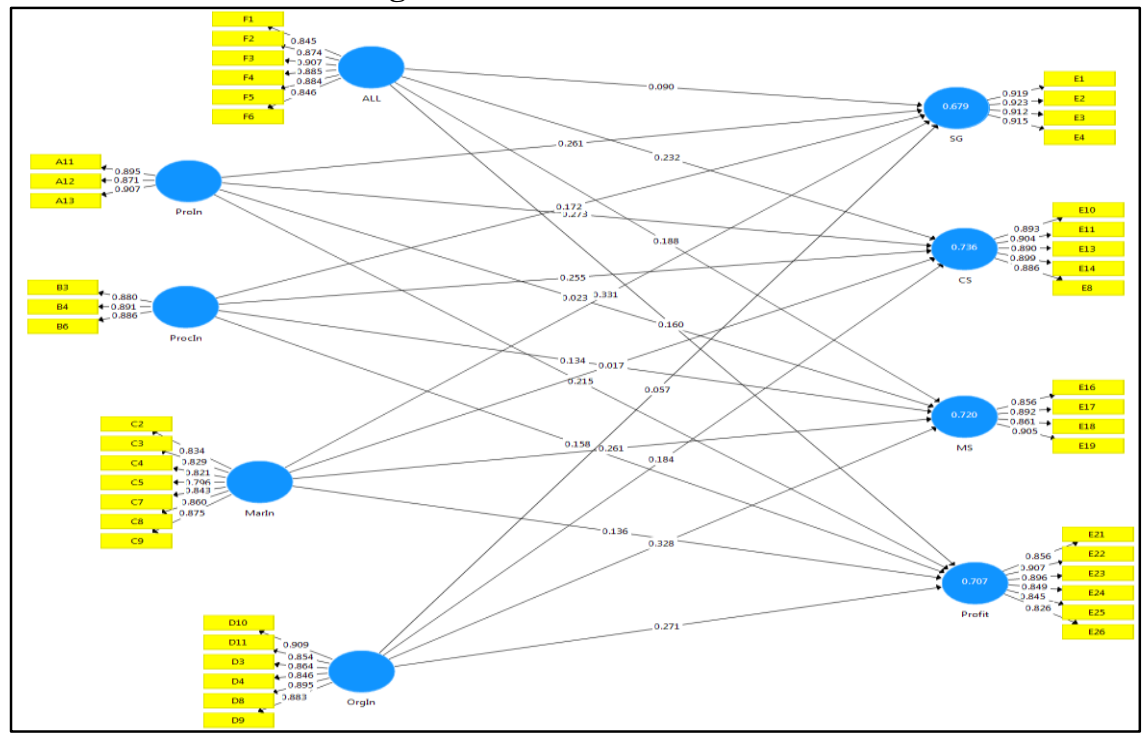

\subsubsection{Convergent Validity}

Convergent validity is the degree to which multiple items to measure the same concept are in agreement. According to Hair et al. (2016) convergent validity can be achieved if the loading is higher than 0.5, the average variance explained (AVE) is higher than 0.5 and the composite reliability $(\mathrm{CR})$ is higher than 0.7 . Based on Table 2 , all the values for loading, AVE and composite reliability surpass the minimum threshold values set by Hair et al. (2016). Loadings are in the range of $0.796-0.923$, AVE in the range of $0.702-0.841$ and the composite reliability is in the range of $0.916-0.946$, thus, it can be confirmed that the convergent validity has been established for the study.

Table 2: Reliability and Validity Result of Measurement Model

\begin{tabular}{|c|c|c|c|c|c|c|}
\hline \multirow[b]{2}{*}{ Construct } & \multirow[b]{2}{*}{ Dimension } & \multirow[b]{2}{*}{ Item } & \multirow{2}{*}{$\begin{array}{c}\begin{array}{c}\text { Indicator } \\
\text { Reliability }\end{array} \\
\text { Loading } \\
>\mathbf{0 . 7 0}\end{array}$} & \multicolumn{2}{|c|}{ "Internal Consistency } & \multirow{2}{*}{$\begin{array}{c}\begin{array}{c}\text { Convergent } \\
\text { Validity }\end{array} \\
\text { AVE } \\
>\mathbf{0 . 5 0}\end{array}$} \\
\hline & & & & $\begin{array}{c}\text { CR } \\
>0.70\end{array}$ & $\begin{array}{c}\text { Cronbach's } \\
\text { Alpha } \\
>0.70\end{array}$ & \\
\hline \multirow{9}{*}{$\begin{array}{l}\text { Innovation } \\
\text { Capabilities }\end{array}$} & \multirow{3}{*}{$\begin{array}{l}\text { Product } \\
\text { Innovation }\end{array}$} & A11 & 0.895 & \multirow{3}{*}{0.920} & \multirow{3}{*}{0.871} & \multirow{3}{*}{0.794} \\
\hline & & A12 & 0.871 & & & \\
\hline & & A13 & 0.907 & & & \\
\hline & \multirow{3}{*}{$\begin{array}{l}\text { Process } \\
\text { Innovation }\end{array}$} & B3 & 0.880 & \multirow{3}{*}{0.916} & \multirow{3}{*}{0.863} & \multirow{3}{*}{0.785} \\
\hline & & B4 & 0.891 & & & \\
\hline & & B6 & 0.886 & & & \\
\hline & \multirow{3}{*}{$\begin{array}{c}\text { Market } \\
\text { Innovation }\end{array}$} & $\mathrm{C} 2$ & 0.834 & \multirow{3}{*}{0.942} & \multirow{3}{*}{0.929} & \multirow{3}{*}{0.701} \\
\hline & & $\mathrm{C} 3$ & 0.829 & & & \\
\hline & & $\mathrm{C} 4$ & 0.821 & & & \\
\hline
\end{tabular}




\begin{tabular}{|c|c|c|c|c|c|c|}
\hline \multirow{12}{*}{ Construct } & \multirow[b]{2}{*}{ Dimension } & \multirow[b]{2}{*}{ Item } & \multirow{2}{*}{$\begin{array}{c}\text { Indicator } \\
\text { Reliability } \\
\text { Loading } \\
>0.70\end{array}$} & \multicolumn{2}{|c|}{ Internal Consistency } & \multirow{2}{*}{$\begin{array}{c}\begin{array}{c}\text { Convergent } \\
\text { Validity }\end{array} \\
\text { AVE } \\
>0.50 \\
\end{array}$} \\
\hline & & & & $\begin{array}{c}\text { CR } \\
>0.70 \\
\end{array}$ & $\begin{array}{c}\text { Cronbach's } \\
\text { Alpha } \\
>0.70\end{array}$ & \\
\hline & & $\mathrm{C} 5$ & 0.796 & & & \\
\hline & & $\mathrm{C} 7$ & 0.843 & & & \\
\hline & & $\mathrm{C} 8$ & 0.860 & & & \\
\hline & & $\mathrm{C} 9$ & 0.875 & & & \\
\hline & & D3 & 0.864 & & & \\
\hline & & D4 & 0.846 & & & \\
\hline & Organization & D8 & 0.895 & & & \\
\hline & Innovation & D9 & 0.883 & 0.952 & 0.939 & 0.767 \\
\hline & & D10 & 0.909 & & & \\
\hline & & D11 & 0.854 & & & \\
\hline \multirow{19}{*}{$\begin{array}{c}\text { SMEs } \\
\text { Performance }\end{array}$} & \multirow{4}{*}{ Sales Growth } & E1 & 0.919 & \multirow{4}{*}{0.937} & \multirow{4}{*}{0.955} & \multirow{4}{*}{0.841} \\
\hline & & E2 & 0.923 & & & \\
\hline & & E3 & 0.912 & & & \\
\hline & & $\mathrm{E} 4$ & 0.915 & & & \\
\hline & \multirow{5}{*}{$\begin{array}{l}\text { Customer } \\
\text { Satisfaction }\end{array}$} & E8 & 0.886 & \multirow{5}{*}{0.937} & \multirow{5}{*}{0.955} & \multirow{5}{*}{0.799} \\
\hline & & E10 & 0.893 & & & \\
\hline & & E11 & 0.904 & & & \\
\hline & & E13 & 0.890 & & & \\
\hline & & E14 & 0.899 & & & \\
\hline & \multirow{4}{*}{ Market Share } & E16 & 0.856 & \multirow{4}{*}{0.931} & \multirow{4}{*}{0.902} & \multirow{4}{*}{0.772} \\
\hline & & E17 & 0.892 & & & \\
\hline & & E18 & 0.861 & & & \\
\hline & & E19 & 0.905 & & & \\
\hline & \multirow{6}{*}{ Profit } & E21 & 0.856 & \multirow{6}{*}{0.946} & \multirow{6}{*}{0.932} & \multirow{6}{*}{0.746} \\
\hline & & E22 & 0.907 & & & \\
\hline & & E23 & 0.896 & & & \\
\hline & & E24 & 0.849 & & & \\
\hline & & E25 & 0.845 & & & \\
\hline & & E26 & 0.826 & & & \\
\hline \multirow{6}{*}{$\begin{array}{l}\text { Strategic } \\
\text { Alliance }\end{array}$} & & $\mathrm{F} 1$ & 0.845 & \multirow{6}{*}{0.951} & \multirow{6}{*}{0.938} & \multirow{6}{*}{0.763} \\
\hline & & F2 & 0.874 & & & \\
\hline & & F3 & 0.907 & & & \\
\hline & & $\mathrm{F} 4$ & 0.885 & & & \\
\hline & & F5 & 0.884 & & & \\
\hline & & F6 & 0.846 & & & \\
\hline
\end{tabular}

\subsubsection{Discriminant Validity}

The discriminant validity was tested by following the protocol described by Fornell and Larcker (1981). Discriminant validity is the degree where items differentiate among constructs, and is measured by examining the correlation between the potential overlapping constructs (Fornell \& Larcker, 1981). According to Hair et al. (2014), the average variance shared between each construct and its measure should be greater than the variance shared between the constructs and other constructs. Table 3 illustrated that the square root of the AVE (as shown in bold values on the 
diagonals) were greater than the corresponding row and column values which indicate the measure was discriminate. Another method of assessing discriminant validity is by using means of comparing the cross loadings between constructs. It is vital to ensure that each indicator load high on its own constructs but low on other constructs and all indicators in the table fulfil the requirement. It represents discriminant validity is achieved as the constructs value different from each other.

Table 3: Discriminant Validity

\begin{tabular}{lccccccccc}
\hline \hline & ProIn & ProcIn & MarIn & OrgIn & SG & CS & MS & Profit & All \\
\hline ProIn & $\mathbf{0 . 8 9 1}$ & & & & & & & & \\
ProcIn & 0.777 & $\mathbf{0 . 8 8 6}$ & & & & & & & \\
MarIn & 0.754 & 0.783 & $\mathbf{0 . 8 3 7}$ & & & & & & \\
OrgIn & 0.725 & 0.780 & 0.821 & $\mathbf{0 . 8 7 6}$ & & & & & \\
SG & 0.748 & 0.737 & 0.775 & 0.718 & $\mathbf{0 . 9 1 7}$ & & & & \\
CS & 0.780 & 0.776 & 0.743 & 0.765 & 0.785 & $\mathbf{0 . 8 9 4}$ & & & \\
MS & 0.694 & 0.736 & 0.790 & 0.802 & 0.780 & 0.789 & $\mathbf{0 . 8 7 9}$ & & \\
Profit & 0.748 & 0.747 & 0.761 & 0.778 & 0.822 & 0.821 & 0.792 & $\mathbf{0 . 8 6 4}$ & \\
All & 0.697 & 0.652 & 0.729 & 0.731 & 0.667 & 0.736 & 0.722 & 0.710 & $\mathbf{0 . 8 7 4}$ \\
\hline \hline
\end{tabular}

\subsection{Assessment of the Hierarchical Model}

In Figure 3, this study shows the parameters of innovation capabilities and firm performance as a second-order reflective hierarchical construct model using two-stage approach. In Table 4, the results show that the outer loading, composite reliability, Cronbach's alpha and AVE of the second order model is equal to or greater than $0.70,0.60$ and 0.50 respectively, which provides evidence of reliable second order measures. Table 5 shows that discriminant validity is also fulfilled because the AVE in bold is greater than its highest construct's correlation with any other constructs (Hair Jr et al., 2014; Henseler et al., 2009). The cross loadings between constructs also shown that each indicator load high on its own constructs but low on other constructs and all indicators in the table fulfil the requirement of discriminant validity.

Figure 3: Hierarchical Model

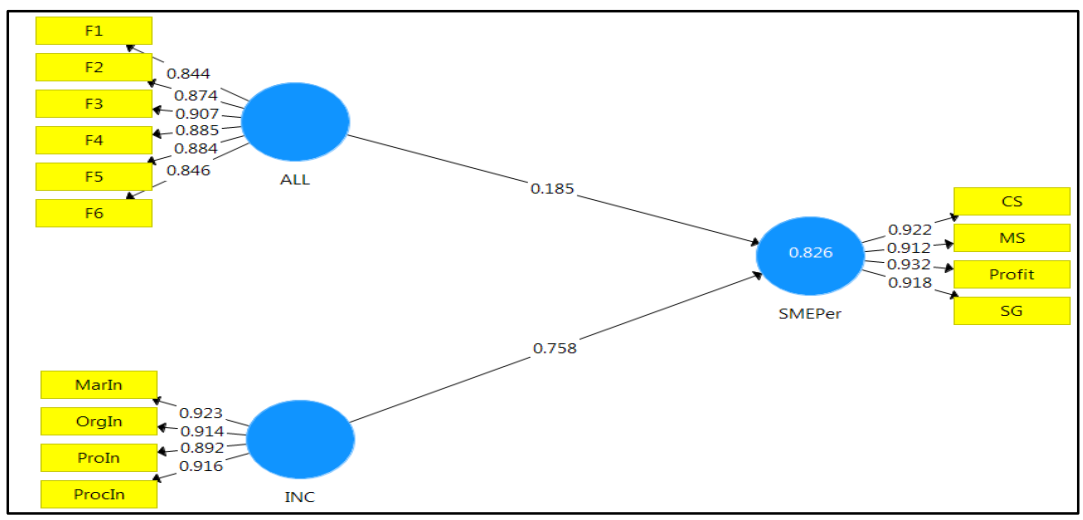


Table 4: Reliability and Validity Result of Second Order Constructs

\begin{tabular}{|c|c|c|c|c|c|}
\hline Construct & Component & $\begin{array}{c}\text { Outer } \\
\text { Loading } \\
>0.70 \\
\end{array}$ & $\begin{array}{r}\text { CR } \\
>0.60 \\
\end{array}$ & $\begin{array}{c}\text { Cronbach's } \\
\text { Alpha } \\
>0.60 \\
\end{array}$ & $\begin{array}{r}\text { AVE } \\
>0.50 \\
\end{array}$ \\
\hline $\begin{array}{l}\text { Innovation } \\
\text { Capabilities }\end{array}$ & $\begin{array}{l}\text { Product innovation } \\
\text { Process innovation } \\
\text { Market innovation } \\
\text { Organization innovation }\end{array}$ & $\begin{array}{l}0.892 \\
0.916 \\
0.923 \\
0.914 \\
\end{array}$ & 0.951 & 0.932 & 0.830 \\
\hline $\begin{array}{c}\text { SMEs } \\
\text { Performance }\end{array}$ & $\begin{array}{l}\text { Sales growth } \\
\text { Customer satisfaction } \\
\text { Profit } \\
\text { Market share }\end{array}$ & $\begin{array}{l}0.918 \\
0.922 \\
0.932 \\
0.912 \\
\end{array}$ & 0.957 & 0.941 & 0.849 \\
\hline $\begin{array}{l}\text { Strategic } \\
\text { Alliance }\end{array}$ & $\begin{array}{l}\text { F1 } \\
\text { F2 } \\
\text { F3 } \\
\text { F4 } \\
\text { F5 } \\
\text { F6 }\end{array}$ & $\begin{array}{l}0.844 \\
0.874 \\
0.907 \\
0.885 \\
0.884 \\
0.846\end{array}$ & 0.951 & 0.938 & 0.763 \\
\hline
\end{tabular}

Table 5: Discriminant Validity of Second Order Constructs

\begin{tabular}{lccc}
\hline \hline & INC & SMEPer & All \\
\hline INC & $\mathbf{0 . 9 1 1}$ & & \\
SMEPer & 0.901 & $\mathbf{0 . 9 2 1}$ & \\
All & 0.771 & 0.770 & $\mathbf{0 . 8 7 4}$ \\
\hline \hline
\end{tabular}

\subsection{Structural Model}

The hypotheses for this study were tested by running a bootstrapping procedure with a resample of 5,000 as suggested by Hair et al. (2014). Figure 4 illustrated the structural model for this study and Table 6 shows path coefficients of respective constructs with its level of significance. The relationship between innovation capabilities (path coefficient $=0.757, \mathrm{t}=13.849, \mathrm{p}<0.01$ ) are positively related to SMEs performance. Thus, HI is supported. Therefore, the higher the level of innovation capabilities, the better SMEs performance is expected to be. With regards to the path coefficient of alliance as a moderator effect in relation to SMEs performance (path coefficient $=$ $0.004, \mathrm{t}=0.101, \mathrm{p}>0.1)$, the results indicate that strategic alliance moderator effect is not significant to SMEs performance. Hence, $\mathrm{H} 2$ is not supported. 
Figure 4: Structural Model

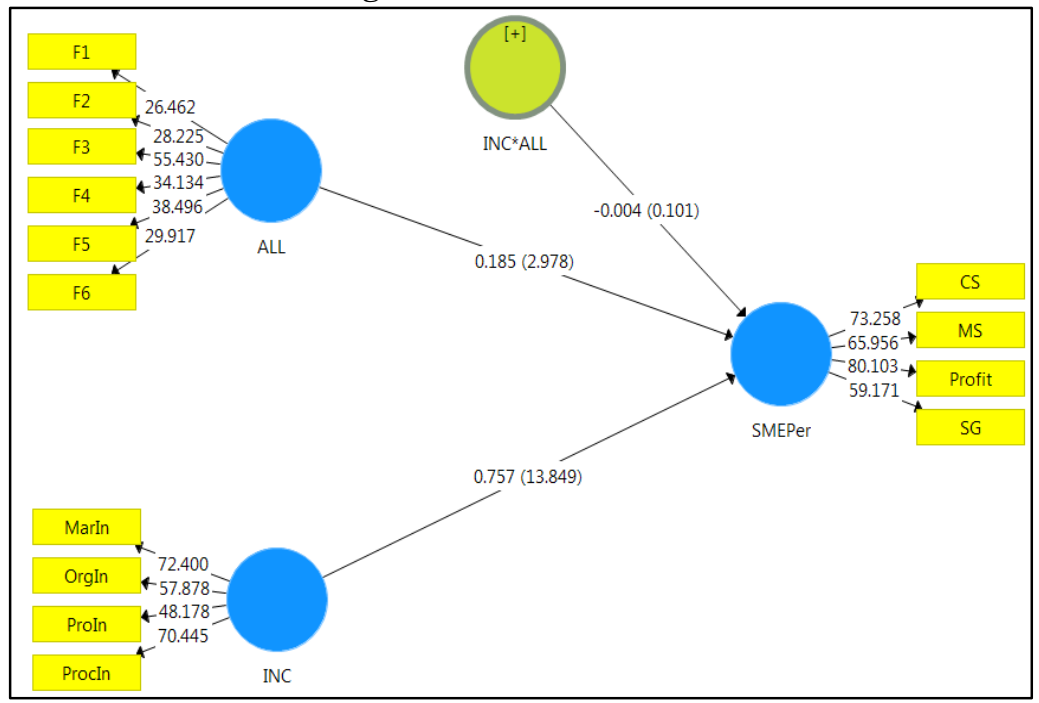

Table 6: Path Coefficient and Hypothesis Testing

\begin{tabular}{cllccccc}
\hline \hline Hypothesis & \multicolumn{1}{c}{ Relationship } & & $\begin{array}{c}\text { Path } \\
\text { Coefficient }\end{array}$ & $\begin{array}{c}\mathrm{t}- \\
\text { value }\end{array}$ & $\begin{array}{c}\text { p- } \\
\text { value }\end{array}$ & Results \\
\hline H1 & $\begin{array}{l}\text { Innovation Capabilities } \\
\text { H2 }\end{array}$ & $\begin{array}{l}\text { Performance } \\
\text { Strategic Alliance Moderator Effect } \rightarrow\end{array}$ & -0.004 & 0.101 & 0.920 & $\begin{array}{c}\text { Not } \\
\text { Supported }\end{array}$ \\
\hline \hline
\end{tabular}

Note: $* * * \mathrm{p}<0.01(2.57), * * \mathrm{p}<0.05(1.96), * \mathrm{p}<0.1(1.65)$

\subsubsection{Assessment of Effect Size}

The $\mathrm{R}^{2}$ for SMEs performance was a strong 0.826 , which meant that innovation capabilities and alliance explained about $82.6 \%$ of variance of firm performance. We found that $85 \%\left(\mathrm{R}^{2}=0.826\right)$ of the performance of agricultural SMEs was contributed by innovation capabilities while the excess of $17.4 \%$ was contributed by other factors. Additionally, the effect size $\left(f^{2}\right)$ has been assessed. The results in Table 7 shows the effect size of the particular exogenous construct on the respective endogenous construct. The result indicates that innovation capabilities have large effect size on the SMEs performance and alliance has small effect size on the respective endogenous construct as suggested by Cohen (1988). Moreover, predictive relevance of the model by using the blindfolding procedure has been assessed. If the $Q 2$ values are greater than 0 it revealed that model has predictive relevance for a certain endogenous construct (Hair Jr et al., 2014; Henseler et al., 2009). Table 7 showed that the values of $\mathrm{Q}^{2}$ is 0.655 , which means that the proposed model has significant predictive relevance. 
Table 7: Results of $\mathrm{R}^{2}, \mathrm{Q}^{2}$ and Effect Size $\left(f^{2}\right)$

\begin{tabular}{|c|c|c|c|c|c|}
\hline Relationship & & $\overline{\mathrm{R}^{2}}$ & $\overline{\mathrm{Q}^{2}}$ & $f^{2}$ Value & $\begin{array}{c}\text { Effect } \\
\text { Size }\end{array}$ \\
\hline $\begin{array}{l}\text { Innovation Capabilities } \\
\text { Performance }\end{array}$ & -> SMEs & 0.826 & 0.655 & 1.339 & Large \\
\hline $\begin{array}{l}\text { Strategic Alliance Moderator Effect } \\
\text { Performance }\end{array}$ & -> SMEs & & & 0.080 & Small \\
\hline
\end{tabular}

\section{DISCUSSION, LIMITATION AND RECOMMENDATIONS OF FUTURE STUDIES}

In general, the results of this study show that entrepreneurs with the higher level of innovation capabilities, have potential to increase agricultural SMEs performance. This result is consistent with Abd Aziz and Samad (2016), Adnan and Ahmad (2016), Asree et al. (2010) and Hassan et al. (2014), of which their studies have been conducted in different sectors such as food manufacturing, wood and timber industry, and hotel industry respectively. We find evidence that increasing the innovation capabilities is very important and significant for SMEs performance. SMEs are being consistently outperforming the overall Malaysian GDP, averaging at $6.6 \%$ per annum compared to $5.1 \%$ growth for the overall GDP (SME Corporation Malaysia, 2016), have important roles in providing job opportunities, increasing the exports of the country, and improving the country's economic growth. SMEs, which can be established for any types of business activities in urban or rural area, can be considered as the backbone of the national economy. However, as compared to other developing countries, the contribution of Malaysian SMEs of 32.5\% from the national GDP is still considered low in comparison to their representation in the total business establishment of 97.3\% (Thaker et al., 2013). Malaysian SMEs have been confronted with many issues and challenges including access to financing, lack of human capital, infrastructure, innovation and technology, legal and regulations and access to marketing (Abdul Razak et al., 2018). The ever changing and uncertain economic environment have called for more innovation as a source of sustainable development of the businesses (Othman \& Jafari, 2014).

In the agricultural sector, in facing the challenges of globalisation and open market competition, SMEs need to improve productivity and reduce production costs through the adoption of an innovative culture and the use of latest technology and production methods. The capability of innovation and the creation of new technologies, will be able to solve the problems faced by agricultural sector catalysts and thus contribute to the impact of increased agricultural output (Turner et al., 2016). In addition, global market expansion and increased local populations lead to an increase in demand for agricultural products. Hence, the agricultural sector needs to step up efforts to advance the country's established agricultural technology to drive new innovations, thereby enhancing the production and quality of agricultural products to meet the needs of Malaysians and the global market demand (Mannan \& Nordin, 2014). By adopting innovations in order to penetrate foreign market, this development is beneficial to increase competitive advantage for most organizations (Azar \& Ciabushi, 2017). Therefore, our study proposed that one of the recommended strategies is to increase more strategic alliances among entrepreneurs to strengthen SMEs resources and innovation capabilities in penetrating new market.

This is consistent with the recent recommendation of the former Malaysia's Prime Ministry, Tun Dr. Mahathir Mohamad for paddy farmers in Kedah (Ikhsan et al., 2019). The farmers have been 
advised to form alliances to incorporate technology and bigger resources of land in producing a big scale of national rice industry. By taking FELDA and Sime Darby experience in managing palm oil and plantation industries, Tan Sri Mohd. Bakke Salleh was mentioned by Tun to lead the taskforce for this idea. Therefore, we also think that in order to succeed in a long term and bigger scale of market competition, SMEs are recommended to form strategic alliances which is similar to the strategy taken by some successful stories. The strategic alliances will enable the SMEs to venture better innovation capabilities and better performance. According to Maimunah (2018), one of the biggest mergers in Malaysia history is the success of combining three plantation companies namely Golden Hope, Guthrie and Sime Darby to become a mega-sized plantation company which is now well known as Sime Darby Bhd.

In a hindsight, the definition of company alliance used for this study is to emphasis on alliances and acquisitions of companies. Although we had backed up by Resource-Based View Theory and Schumpeter Innovation Theory, our study shows a non-significant effect of strategic alliances as moderator between innovation capabilities and SMEs performance. Moreover, the explanation of this result can be considered on the following factors. For agricultural SMEs in Malaysia, the process of alliances and acquisitions of enterprises may be quite difficult to implement as the majority of Malaysian agricultural SMEs are small in size. This is the reason entrepreneurs are not keen to merge due to the small size of their enterprises, which will cause them to face problems and difficulties to share a small amount of profits compared to the earnings and profits earned by larger companies. In general, agricultural SMEs in Malaysia are more involved in joint venture processes with government agencies in the form of joint venture related resources and agricultural projects such as FAMA Contract Farming Project (Projek Pertanian Kontrak FAMA) and group farming project (Buang \& Suryandari, 2009; Buang et al., 2010). If we consider strategic alliances as a source to influence innovation capabilities and competitive advantage in entering to a new market, then an innovation strategy is arguably affected and influenced by the organizational behaviour and stands (Azar \& Ciabushi, 2017).

It seems that in Malaysian context, innovation and technology output will be more successful with the collaboration between SME entrepreneurs and government agencies and also with institutes of higher learning (Chandran et al., 2014; Said et al., 2012). This is because the agricultural sector is no longer seemed to be the sector that produces products for the farmers and local market. But the agricultural sector has become a commercial area for agricultural entrepreneurs and SMEs to produce and market agricultural products that can help the country in enhancing the economic capability and national income for international market. In addition, this sector needs to undergo a revolution so that it will be able to attract young people to get involved actively in agricultural SMEs. Development of the agricultural sector can reduce the import of food from outside of the country and promote the development and growth of agricultural SMEs. Therefore, agricultural SMEs require a transformation in the innovation field to improve their performance. Changes in people's mind-sets are crucially important to accept and adapt to a new innovation way of thinking and strategic alliances for further improvement.

\subsection{Limitation and Direction for Future Research}

This study provided some useful insights into innovation capabilities and agricultural SMEs performance. However, there were several limitations to the approach used. First, we used scales adopted from several resources for measuring innovation capabilities such as Community 
Innovation Survey (2008), Gunday et al. (2011) and Škerlavaj et al. (2010). Although these scales have advantages in reflecting 4 dimensions of innovation capabilities, future studies could perhaps apply more comprehensive measures including other dimensions of innovations. Second, the crosssectional method applied in this study could not cover Sabah and Sarawak states due to logistic and poor response rate. Future studies should consider a wider SMEs coverage including different sub-sectors of agricultural field such as biotechnology, traditional medicine and herbs or high valued agriculture sector (ie. seaweed, bird nest and aquaculture). A higher number of SMEs response rates could possibly counter generalizability issue. Third, our study faced insignificant result of strategic alliance as moderator variable for agriculture sector which it might be due to least practiced strategy. Therefore, future studies might also consider other barrier and driving factors such as funds, government incentives and joint ventures for better insights.

\section{CONCLUSION}

Overall, the findings of this study are seen as providing added value to government agencies such as Ministry of Science, Technology and Innovation (MOSTI) and SME Corporation Malaysia (SME Corp. Malaysia) in improving the innovation policies in attracting young generations to involve in agricultural SMEs.

\subsection{Theoretical Implications}

This study contributes by enriching the academic literature and provides practical implications. Two hypotheses are set in relation to the link between innovation capabilities and performance, and the moderating effect of strategic alliance on the relation between innovation capabilities and performance.

In terms of academic literature and theoretical implications, this study applied the Schumpeter Innovation Theory to develop a proxy for companies' innovation capabilities based on four components of innovation; product, process, market and organization. Studies that employ a comprehensive aspect of innovation to measure innovation capabilities are limited (Rhee et al., 2010 ) as many tend to focus on only one or two aspects of innovation (Che-Ha \& Mohd-Said, 2012; Hilmi et al., 2010; Samad, 2012; Zakaria et al., 2016).

Other than that, this study incorporates strategic alliance as the moderating factor on the relation between innovation capabilities and performance, as to further understand whether the benefit of the innovation capabilities can be enhanced with having strategic alliance. This approach is undertaken to add to the findings of the prior studies that mainly explore the effect of strategic alliance on performance of companies (Doh \& Kim, 2014; Kang et al., 2013; Mukherjee et al., 2013; Nieto \& Santamaría, 2010; Wonglimpiyat, 2011; Zhang \& Yin, 2012). The research objectives are also set in line with the Resource-Based View theory that the competitive advantage of an organization is not solely dependent on the market conditions and the characteristics of the industry, but more on the internal resources that the organizations have and can utilize (Kumlu, 2014). 


\subsection{Practical Implications}

In terms of practical implications, findings of this study can assist the government agencies, such as Kementerian Pertanian dan Industri Asas Tani, Kementerian Sains, Teknologi dan Inovasi (MOSTI), Perbadanan Pembangunan Industri Kecil dan Sederhana (SMIDEC), and Bank Perusahaan Kecil \& Sederhana Malaysia Berhad (SME Bank). The expected contributions are in terms of assisting them in developing the measurement index of innovation capabilities, improving existing and new policies, and enhancing the efforts of attracting young generations to be involved in agriculture SMEs in Malaysia. These contributions are expected to contribute to the enhancement of the role of the agriculture sector in escalating the Malaysian social and economic development.

This study aims to help the Malaysian government in motivating the young generation to involve in agriculture sector. Agriculture sector can act as the problem solver for the unemployment issue. However, although its ability to overcome such issues, it seems that youth are not preferring agriculture and it is due to their negative attitudes towards agriculture (Dsilva et al., 2010; Man \& Hamzah, 2007). The youth are not interested to join agriculture because they thought that this sector is not an attractive area to work and does not provide good income (Man \& Hamzah, 2007). To attract the youth to involve in agriculture sector, the Malaysian government has continuously encouraged the involvement of youths in entrepreneurship. In 2013, the Ministry of Agriculture and Agro-based Industry (MOA) has established Young Agropreneur Unit (Kadir, 2013). The main objective of the Young Agropreneur Unit is to inculcate interest among young generation towards agriculture sector and develop a group of high-income young agriculture entrepreneurs. This programme is designed specifically for young people under the age of 40 . The approach of this program is to facilitate and encourage the involvement of the target group in entrepreneurship based on agricultural activities including all activities within the agricultural industry value chain encompasses the agricultural sector such as crops, livestock, fisheries, marketing, technology and innovation, as well as special projects such as agro-tourism and agro-based industry (Kadir, 2013).

This study also helps entrepreneurs to expand their business sizes and educational level in term of employee skills and competence workforce. Therefore, government agencies such as SME Corporation, the Ministry of Agriculture and Agro-based Industry, the Ministry of Human Resources and FAMA need to enhance and strengthen their management and capabilities that will drive SME entrepreneurs towards innovating business growth and becoming successful business community. The implementation of INSKEN500 program by the National Entrepreneurship Institute (INSKEN) is responsible to provide comprehensive entrepreneurial skills and knowledge to build sustainable businesses through business counselling, training, consulting and business assistance. The development of such programs for agricultural SMEs needs to be enhanced in ensuring the entrepreneurs are able to compete and maintain their business in competitive business environment (Abdul Manaf et al., 2012).

In conclusion, the development of SMEs is very important in the country's economic development. Upon the realisation, SME entrepreneurs need to be more proactive and committed to produce quality products and prepare to venture into the high-tech agricultural sector. 


\section{REFERENCES}

Abd Aziz, N. N., \& Samad, S. (2016). Innovation and competitive advantage: Moderating effects of firm age in foods manufacturing SMEs in Malaysia. Procedia Economics and Finance, 35, 256-266.

Abdul Manaf, A., Omar, N. H., \& Lee, K. Y. (2012). Faktor kritikal kejayaan usahawan dalam perniagaan. e-Bangi: Journal of Human Sciences and Humanities, 7(1), 34 - 45.

Abdul Razak, D., Abdullah, M. A., \& Ersoy, A. (2018). Small medium enterprises (SMEs) in Turkey and Malaysia A comparative discussion on issues and challenges. International Journal of Business, Economics and Law, 10(49), 2-591.

Adnan, Z. S., \& Ahmad, H. (2016). Inovasi dalam perusahaan kecil dan sederhana (PKS) pembuatan makananan dan minuman. Journal of Global Business and Social Entrepreneurship, 1(1), 79-88.

Ahmad, N. A., Ab Hamid, K., \& Othman, Z. (2014). Potensi penerima guna inovasi pertanian di kalangan petani. Prosiding PERKEM, 9, $311-320$.

Armbruster, H., Bikfalvi, A., Kinkel, S., \& Lay, G. (2008). Organizational innovation: The challenge of measuring non-technical innovation in large-scale surveys. Technovation, 28(10), 644-657.

Asree, S., Zain, M., \& Rizal Razalli, M. (2010). Influence of leadership competency and organizational culture on responsiveness and performance of firms. International Journal of Contemporary Hospitality Management, 22(4), 500-516.

Azar, G., \& Ciabuschi, F. (2017). Organizational innovation, technological innovation, and export performance: The effects of innovation radicalness and extensiveness. International Business Review, 26(2), 324-336.

Buang, A., \& Suryandari, R., Y. (2009). Pertanian kontrak sebagai satu kaedah memajukan petani kecil melayu: Tanggapan dan penilaian komuniti tani tempatan di Zon Utara, Semenanjung Malaysia terhadap prestasi program pertanian kontrak FAMA. Malaysian Journal of Society and Space, 5(1), 11-22.

Buang, A., Abdullah, M. A., \& Mohd Zainol, R. (2010). Memajukan petani kecil melayu menerusi pertanian kontrak - Persepsi dan penilaian peserta projek dan komuniti tempatan. Malaysian Journal of Society and Space, 6(1), 68-80.

Chandran, V. G. R., Sundram, V. P. K., \& Santhidran, S. (2014), Innovation systems in Malaysia: A perspective of university-industry R\&D collaboration. AI and Society, 29(3), 435-444.

Che-Ha, N., \& Mohd Said, S. (2012). Innovation practices by Malaysian SMEs. In Che-Ha, N., \& Mahmood, A. (Eds.), Malaysian SMEs in The New Economy (pp. 39-58). Petaling Jaya: Cengage Learning Asia Pte Ltd.

Cho, H. J., \& Pucik, V. (2005). Relationship between innovativeness, quality, growth, profitability, and market value. Strategic Management Journal, 26(6), 555-575.

Chow, Y. K. (2016). The moderating role of dynamic capability between strategic orientations and firm performance in Malaysia agro based SME (Doctoral dissertation, Universiti Utara Malaysia, Kedah, Malaysia). http://etd.uum.edu.my/6373/2/s92663_01.pdf

Cohen, J. (1988). Statistical power analysis for the behavioural sciences ( $^{\text {nd }}$ ed.). Hillsdale, New Jersey: Erlbaum.

Community Innovation Survey. (2008). Government of Ireland. https://ec.europa.eu/eurostat/documents/203647/203701/CIS_Survey_form_2008.pdf/e06 a4c11-7535-4003-8e00-143228e1b308 
Cruz-Cázares, C., Bayona-Sáez, C., \& Garcia-Marco, T. (2010). R\&D strategies and firm innovative performance: A panel data analysis. International Journal of Innovation Management, 14(6), 1013-1045.

Dsilva, J., Shaffril, H. A. M., Uli, J., \& Samah, B. A. (2010). Socio-demography factors that influence youth attitude towards contract farming: A case from Peninsular Malaysia. American Journal of Applied Sciences, 7(4), 603 - 608.

Doh, S., \& Kim, B. (2014). Government support for SME innovations in the regional industries: The case of government financial support program in South Korea. Research Policy, 43(9), 1557-1569.

Fornell, C., \& Larcker, D. F. (1981). Evaluating structural equation models with unobservable variables and measurement error. Journal of Marketing Research, 18(1), 39-50.

Gliem, J. A., \& Gliem, R. R. (2003). Calculating, interpreting, and reporting cronbach's alpha reliability coefficient for likert-type scales. Midwest Research-To-Practice Conference in Adult, Continuing, and Community Education. https://scholarworks.iupui.edu/bitstream/handle/1805/344/Gliem\%20\%26\%20Gliem.pdf? sequence $=1 \&$ isAllowed $=y$

Gunday, G., Ulusoy, G., Kilic, K., \& Alpkan, L. (2011). Effects of Innovation Types on Firm Performance. International Journal of Production Economics, 133(2), 662-676.

Hair, J. F., Hult, G. T. M., Ringle, C. M., \& Sarstedt, M. (2014). A primer on partial least squares structural equation modelling (PLS - SEM). Thousand Oaks, CA: Sage Publication.

Hair, J. F., Hult, G. T. M., Ringle, C., \& Sarstedt, M. (2016) A Primer on Partial Least Squares Structural Equation Modeling (PLS-SEM). USA: Sage Publications.

Hassan, T. M., Yaacob, M. R., \& Abdullatiff, N. K. (2014). Sustaining SMEs wood-based product manufacturing through best practices - The case of indigenous entrepreneurs in Kelantan. Procedia - Social and Behavioural Sciences, 115, 221-234.

Henseler, J., Ringle, C. M., \& Sinkovics, R. R. (2009). The use of partial least squares path modeling in international marketing. In New Challenges to International Marketing (pp.277-319). Emerald Group Publishing Limited.

Hilmi, M. F., Ramayah, T., Mustapha, Y., \& Pawanchik, S. (2010). Product and process innovativeness: Evidence from Malaysian SMEs. European Journal of Social Sciences, 16(4), 556-564.

Ikhsan, H. M., Amran, S. N. M. E., \& Abdul Rahman, N. (2019, September 10). Pesawah kecil perlu cantum tanah. Online. https://www.bharian.com.my/berita/nasional/2019/09/605525/pesawah-kecil-perlucantum-tanah

Išoraite, M. (2009). Importance of strategic alliances in company's activity. Intellectual Economics, 1(5), 39-46.

Jabatan Perangkaan Malaysia. (2018). Statistik Ekonomi Tahunan 2018 Sektor Pertanian. Kuala Lumpur.

Jouanjean, M. (2019). Digital Opportunities for Trade in the Agriculture and Food Sectors. $O E C D$ Food, Agriculture and Fisheries Papers, 122. OECD Publishing, Paris.

Kadir, M. K. A. (2013, October 20-24). Development of Young Agropreneur in Malaysia. Paper submitted for the FFTC-RDA International Seminar on Enhanced Entry of Young Generation into Farming, Jeonju, Korea.

Kang, J., Gwon, S.-H., Kim, S., \& Cho, K. (2013). Determinants of successful technology commercialization: implication for Korean government-sponsored SMEs. Asian Journal of Technology Innovation, 21(1), 72-85. 
Karabulut, A. T. (2015). Effects of innovation types on performance of manufacturing firms in Turkey. Procedia-Social and Behavioral Sciences, 195, 1355-1364.

Kumlu, Ö. (2014). The effect of intangible resources and competitive strategies on the export performance of small and medium sized enterprises. Procedia-Social and Behavioural Sciences, 150, 24-34.

Kostopoulos, K. C., Spanos, Y. E., \& Prastacos, G. P. (2002). The Resource-Based View of the Firm and Innovation: Identification of Critical Linkages. http://ecsocman.hse.ru/data/165/663/1219/rb_view.pdf

Lammi, I. (2012). Strategic alliances and three perspectives: A review of literature on alliances. (Master Thesis, Mälardalen University, Sweden). http://www.divaportal.org/smash/get/diva2:604397/FULLTEXT01.pdf

Maimunah, A. (2018). Human Resource Management: Principles and Practices (4 ${ }^{\text {th }}$ ed.). Shah Alam: Oxford Press.

Man, N., \& Hamzah, A. (2007). Keperluan program pendidikan pertanian di kalangan beliatani di kawasan luar bandar. Serdang, Selangor: Universiti Putra Malaysia.

Mannan, S., \& Nordin, S. M. (2014). The Influence of Innovation Attributes on New Technologies Adoption by Paddy Farmers. International Review of Management and Business Research, 3(3), 1379-1384.

Mohamad, M. R., \& Sidek, S. (2013). The impact of innovation on the performance of small and medium manufacturing enterprises: Evidence from Malaysia. Journal of Innovation Management in Small \& Medium Enterprise, 2013, 1-16.

Muhammad, M. Z., Char, A. K., Yasoa', M. R., \& Hassan, Z. (2010). Small and medium enterprises (SMEs) competing in the global business environment: A case of Malaysia. International Business Research, 3(1), 66-75.

Mukherjee, D., Gaur, A. S., Gaur, S. S., \& Schmid, F. (2013). External and internal influences on R\&D alliance formation: Evidence from German SMEs. Journal of Business Research, 66(11), 2178-2185.

Ng, H. S., \& Kee, D. M. (2013). SME innovation: Issues and effect on firm performance: A literature review. Proceedings of the $10^{\text {th }}$ AAM International Conference 2013.

Nieto, M. J., \& Santamaría, L. (2010). Technological collaboration: Bridging the innovation gap between small and large firms. Journal of Small Business Management, 48(1), 44-69.

OECD/FAO (2017). OECD-FAO agricultural outlook 2017-2026. http://www.fao.org/3/I7465e/I7465e.pdf

Omar, S. S., Arokiasamy, L., \& Ismail, M. (2009). The background and challenges faced by the small medium enterprises. A human resource development perspective. International Journal of Business and Management, 4(10), 95-102.

Othman, J., \& Jafari, Y. (2014). Selected research issues in the Malaysian agricultural sector. Jurnal Ekonomi Malaysia, 48(2), 127-136.

Peng, D. X., Schroeder, R. G., \& Shah, R. (2008). Linking Routines to Operations Capabilities: A New Perspective. Journal of Operations Management, 26(6), 730-748.

Polder, M., Leeuwen, G. V., Mohnen, P., \& Raymond, W. (2010). Product, process and organizational innovation: Drivers, complementarity and productivity effects. SSRN Electronic Journal. https://doi.org/10.2139/ssrn.1626805

Ramlan, R., \& Abd Malek, M. (2011). Innovation Key to SMEs Success. University Kuala LumpurBritish Malaysian Institute.

Rezgui, Y., \& Miles, J. (2010). Exploring the potential of SME alliances in the construction sector. Journal of Construction Engineering and Management, 136(5), 558-567. 
Rhee, J., Park, T., \& Lee, D. H. (2010). Drivers of innovativeness and performance for innovative SMEs in South Korea: Mediation of learning orientation. Technovation, 30(1), 65-75.

Ringle, C. M., Wende, S., \& Becker, J-M. (2015). SmartPLS 3. SmartPLS GmbH, Boenningstedt. Rosenbusch, N., Brinckmann, J., \& Bausch, A. (2011). Is innovation always beneficial? A metaanalysis of the relationship between innovation and performance in SMEs. Journal of Business Venturing, 26(4), 441-457.

Said, F. M., Adham, A. K., Abdullah, A. N., Hannienen, S., \& Walsh, T. S. (2012). Incubators and government policy for developing industry and region in emerging economies. Asian Academy of Management Journal, 17(1), 65-96.

Salim, I. M., \& Sulaiman, M. (2011). Organizational learning, innovation and performance: A study of Malaysian small and medium sized enterprises. International Journal of Business and Management, 6(12), 118-126.

Samad, S. (2012). The influence of innovation and transformational leadership on organizational performance. Procedia - Social and Behavioural Sciences, 57, 486-493.

Sarkar, M. B., Echambadi, R., Cavusgil, S. T., \& Aulakh, P. S. (2001). The influence of complementarity, compatibility, and relationship capital on alliance performance. Journal of the Academy of Marketing Science, 29(4), 358-373.

Saunila, M. (2014). Performance management through innovation capability in SMEs (Doctoral Dissertation, Lappeenranta University of Technology, Finland). http://urn.fi/URN:ISBN:978-952-265-614-8

Shahadan, F., Berma, M., Ramlee, S., Idris, N. A., Azhar, Z., \& Abdullah, Z. (2010). Status, performance and success factors affecting SMEs in agriculture and agro-based industries in Malaysia. In Small \& medium enterprises in Malaysia: Potential and prospects (pp. 215248). Ministry of Higher Education.

Škerlavaj, M., Song, J. H., \& Lee, Y. (2010). Organizational learning culture, innovative culture and innovations in South Korean firms. Expert Systems with Application,37(2010), 63906403.

Śledzik, K. (2013). Schumpeter's view on innovation and entrepreneurship. management trends in theory and practice. SSRN Electronic Journal. https://papers.ssrn.com/sol3/Delivery.cfm/SSRN_ID2257783_code1032344.pdf?abstracti $\mathrm{d}=2257783 \&$ mirid $=1$

SME Corporation Malaysia. (2015). SME Annual Report 2015/2016. https://www.smecorp.gov.my/images/Publication/Annual-report/SME\%20AR\%20201516\%20English\%20Final\%20web.pdf

SME Corporation Malaysia. (2016). SME Annual Report 2016/2017. https://www.smecorp.gov.my/index.php/en/laporan-tahunan/2150-sme-annual-report2016-17

Sok, P., O’Cass, A., \& Sok, K. M. (2013). Achieving Superior SME Performance: Overarching role of marketing, innovation, and learning capabilities. Australasian Marketing Journal $(A M J), 21(3), 161-167$.

Stella, A. (2012). Organizational learning, innovation and small and medium enterprise (SME) performance in Uganda (Unpublished Master Dissertation). Makerere University, Uganda.

Thaker, M. T., Asmy, M., \& Mohammed, M. O. (2013). The challenges of micro enterprises in Malaysia and the prospect for integrated cash waqf micro enterprise investment (ICWMEI) model. In Abdullah, M. A., \& Owolabi Yusuf, M. -B. (eds), Small and medium enterprises (SMEs) in selected Muslim countries. Kuala Lumpur: IIUM Press. 
Turner, J. A., Klerkx, L., Rijswijk, K., Williams, T., \& Barnard, T. (2016). Systemic problems affecting co-innovation in the New Zealand Agricultural Innovation System: Identification of blocking mechanisms and underlying institutional logics. NJAS - Wageningen Journal of Life Sciences, 76, 99-112.

Walker, R. M. (2004). Innovation and organisational performance: Evidence and a research agenda. SSRN Electronic Journal. https://papers.ssrn.com/sol3/Delivery.cfm/SSRN_ID1306909_code1099627.pdf?abstracti $\underline{\mathrm{d}=1306909 \& \text { mirid }=1}$

Wonglimpiyat, J. (2011). Government programmes in financing innovations: Comparative innovation system cases of Malaysia and Thailand. Technology in Society, 33(2011), 156164.

Yi, W. (2007). Factors influencing the success of virtual cooperation within Dutch - Chinese strategic alliances (Doctoral Dissertation, University of Twente, Netherlands). https://research.utwente.nl/en/publications/factors-influencing-the-success-of-virtualcooperation-within-dut

Zainal Abidin, N., Mohd Anuar, M. A., \& Abdullah, A. (2015). Penglibatan belia dalam pertanian komersial dan perkembangan industri pertanian di Malaysia. South-East Asian Journal for Youth, Sports \& Health Education, 1(1), 99-108.

Zakaria, N., Abdullah, N. A. C., \& Yusoff, R. Z. (2016). The innovation-performance linkage: Empirical evidence of Malaysian manufacturing SMEs. International Soft Science Conference. UK: Future Academy.

Zeng, S. X., Xie, X. M., \& Tam, C. M. (2010). Relationship between cooperation networks and innovation performance of SMEs. Technovation, 30(3), 181-194.

Zhang, M., \& Yin, X. (2012). The effect of R\&D alliances on the speed of innovation: Evidence from Chinese SMEs. Physics Procedia, 25, 1155-1161. 